\title{
Herpes Zoster Ophthalmicus and Disseminated in an Immunocompetent Child
}

\section{Senkaye-Lagom Aimée Kissou ${ }^{1^{*}}$, Jean Wenceslas Diallo², Abdoul-Salam Ouédraogo ${ }^{3}$, Issouf Konaté4, Yemboado Adolphe Namoano ${ }^{1}$, Boubacar Nacro ${ }^{1}$}

${ }^{1}$ Department of Paediatrics, Sanou Sourô Teaching Hospital, Bobo-Dioulasso, Burkina Faso

${ }^{2}$ Department of Ophtalmology, Sanou Sourô Teaching Hospital, Bobo-Dioulasso, Burkina Faso

${ }^{3}$ Department of Bacteriology/Virology, Sanou Sourô Teaching Hospital, Bobo-Dioulasso, Burkina Faso

${ }^{4}$ Department of Dermatology, Sanou Sourô Teaching Hospital, Bobo-Dioulasso, Burkina Faso

Email: *aimekissou@yahoo.fr

How to cite this paper: Kissou, S.A., Diallo, J.W., Ouédraogo, A.-S., Konaté, I., Namoano, Y.A. and Nacro, B. (2016) Herpes Zoster Ophthalmicus and Disseminated in an Immunocompetent Child. Open Journal of Pediatrics, 6, 257-261. http://dx.doi.org/10.4236/ojped.2016.64036

Received: September 7, 2016

Accepted: October 30, 2016

Published: November 2, 2016

Copyright $\odot 2016$ by authors and Scientific Research Publishing Inc. This work is licensed under the Creative Commons Attribution International License (CC BY 4.0).

http://creativecommons.org/licenses/by/4.0/

\begin{abstract}
Herpes zoster and varicella are the two main clinical presentations of the varicella zoster virus infection. Varicella is the manifestation of primary infection. It is a systemic infection, frequent in childhood. Herpes zoster is a reactivation of the virus. It often occurs in immunocompromised situations such as AIDS. Several localizations can be observed in herpes zoster. Disseminated lesions are rarely described. Authors report a case of ophthalmic and generalized (or disseminated) herpes zoster in an immunocompetent child. No history of previous varicella and no particular medical background or family tare was found. However, maternal varicella when pregnant of our patient was reported. The patient had good nutritional status and no cause of immunosuppression. Immediate evolution was favorable for our patient, but the possibility of long-term complications of herpes zoster ophthalmicus should make consider the advisability of vaccination against varicella-zoster virus in children.
\end{abstract}

\section{Keywords}

Herpes Zoster Ophtalmicus, Disseminated Zoster, Varicella-Zoster Virus, Immunocompetent Child

\section{Introduction}

Herpes zoster is with varicella, the two main clinical forms of the varicella-zoster virus infection. Varicella is the manifestation of primary infection, while herpes zoster corresponds to a reactivation of the virus. Varicella is common in children while cases of herpes zoster are relatively rare and often occur in situations of immunosuppression. 
Herpes zoster rash usually concerns one or two adjacent dermatomes. Generalized (or disseminated) zoster is defined by more than 20 vesicles outside the primary and immediately adjacent dermatomes [1]. It's sometimes called varicella-zoster. Ophthalmic zoster can lead to early or late-stage complications [2]. The authors report a case of generalized zoster with ophthalmic location in an immunocompetent child.

\section{Case Report}

A 12 year-old girl was admitted in the pediatrics emergency with rash in the left side of the forehead. This rash appeared six days earlier in a context of sharp pain of the affected area and moderate hyperthermia. Disseminated vesicles had appeared on the trunk along with facial rash. On admission, an important hemi-facial edema was observed, with occlusion of the left eye. Skin lesions associated vesicles, bubbles, pustules and necrotic areas. They were localized on the left hemi-forehead, going up into the scalp, reaching the entire upper eyelid and going down up the left wing of the nose (Figure 1).

Umbilicated vesicles, scarring as well as scratch marks were also found on the trunk (Figure 2).

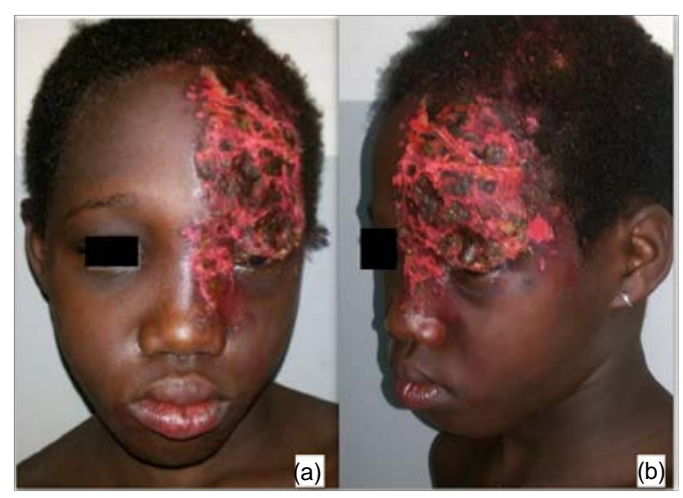

Figure 1. Photographs of patient's head (face (a) and profile (b)) taken at admission, showing skin lesions associating vesicles, bubbles, pustules and necrotic areas.

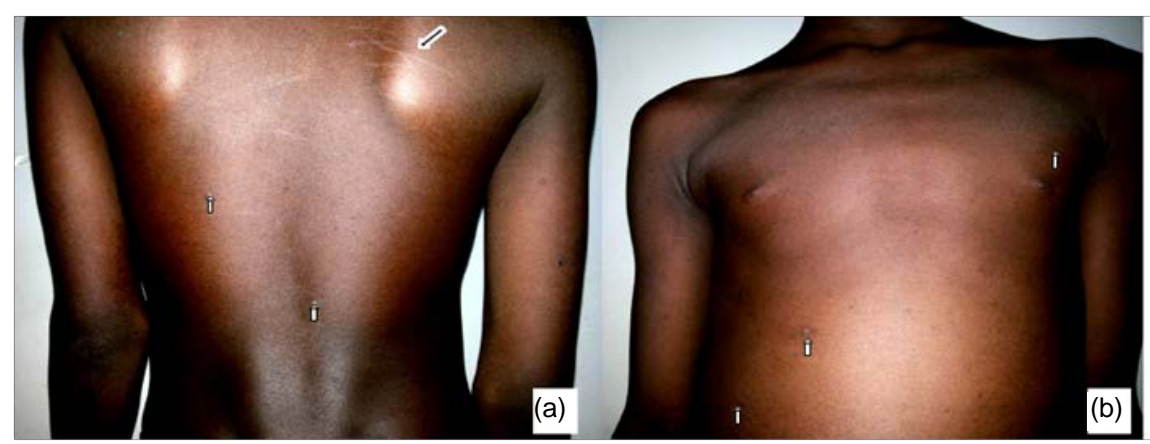

Figure 2. Photographs of patient's trunk (back (a) and front (b)) showing umbilicated vesicles, scarring $(\Longrightarrow)$ and scratch marks $(\longrightarrow)$. 
In addition to skin abnormalities, the patient presented fever (temperature $=39^{\circ} \mathrm{C}$ ) and impaired general condition. This young patient had good nutritional conditions on view of her anthropometric parameters: weight: $31 \mathrm{~kg}$; Height: $138 \mathrm{~cm}$; Z-score/T: between -1 and -2 SD; BMI: 17.5; BMI Z-Score: between median and -1 SD.

Ophthalmologic examination mentioned the eyelid skin lesions; the cornea was healthy with a negative fluorescein test. There were no signs of iritis or uveitis. The rest of the examination was normal.

The patient had received no vaccine against varicella-zoster virus. No history of previous varicella was found. However, her mother would have presented an eruptive disease diagnosed as varicella during pregnancy. The corresponding gestational age had not been specified. The patient had also no particular medical history and no familial or personal tare was mentioned. She didn't receive no immunosuppressive or corticosteroid therapy.

A work-up objectivized a near-normal blood count (discrete lymphocytosis and eosinophilia), normal renal and hepatic functions, AA hemoglobin electrophoresis and negative HIV status. Blood cultures were negative. CD 4 count was $1150 / \mathrm{mm}^{3}$. Biological diagnosis of viral infection could not be performed due to the inadequacy of the technical platform.

The diagnostic of disseminated zoster with superinfected herpes zoster ophtalmicus was posed.

The treatment associated oral acyclovir, large spectrum antibiotic therapy (ceftriaxone and gentamicin, in order to prevent bacteriema) antipyretic (intravenous paracetamol), anti-inflammatory drug (ibuprofen), antihistamine (loratadine), local treatment of skin lesions (solubacter, bactroban) and eyes (Indocollyre).

The evolution was good after 3 days, with improvement of patient condition and fever. Edema and pain regressed progressively. The breaking of vesicles, pustules and bubbles made place to ulcerative and crusted lesions (Figure 3 ). The patient went home after 11 days (in hospital) with her acyclovir and oral antibiotic.

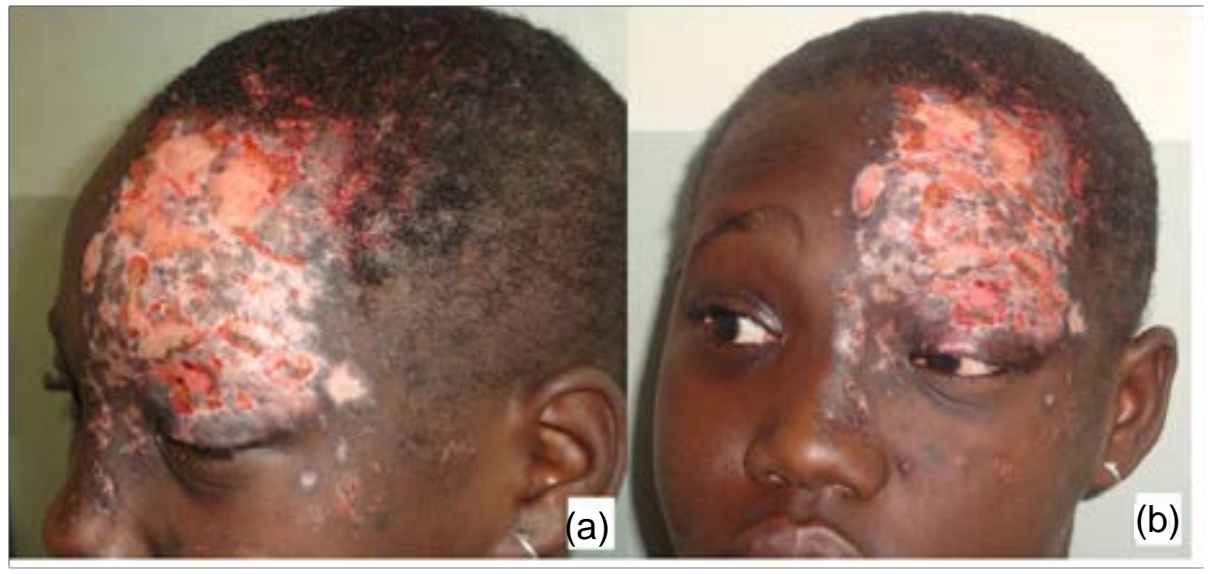

Figure 3. Photographs after 1 week hospitalization of the patient's head (profile (a) and face (b)), showing healing lesions with persistence of upper eyelid's ptosis. 


\section{Discussion}

Varicella-zoster virus is a herpes-virus which has cutaneous and neurologic tropism. Varicella is the manifestation of primary infection by the virus. It is a generalized infection after airborne transmission of the virus. It can be observed at any age, but is mainly the preserve of children. Moreover, congenital varicalla syndrome can be observed after maternal varicella, occurring mainly during the first two trimesters of pregnancy. This syndrome includes multi-organ damage and sometimes poly-malformations. The risk of congenital varicella is variable but usually low (less than 1\%) [3] [4].

Herpes zoster corresponds to a reactivation of dormant virus in sensory ganglia cells after varicella. It appears in most cases in a context of weakening immune defenses. Cell-mediated immunity is particularly concerned. Some cases of herpes zoster are reported in immunocompetent children [5] [6] [7] [8]. Very rare neonatal cases are reported in the literature [9]. Vaccination against varicella-zoster virus can also lead to herpes zoster in children. This risk is in some countries, one of the reasons limiting the promotion of routine immunization of children [10]; this, especially since the vast majority of cases of varicella in children remains without major complications [11].

Herpes zoster in children often follows varicella usually occurring during early childhood. Maternal varicella during pregnancy can also be the cause of herpes zoster in children, as is the case for our patient. These cases of pediatric zoster occur after the disappearance of maternal antibodies. However, the disease is often observed during the first years of life of the child [4].

The rash in herpes zoster relates generally a single nervous territory. Varied dermatomes can be affected, and rare cases of generalized zoster are sometimes observed.

In ophthalmic location, the disease is dominated by corneal injury. The corneal injury must be fear in case of skin lesions situated on the wing of the nose as in our patient; indeed, this situation expresses a pain of the ophthalmic branch of the trigeminal nerve (Willis ophthalmic nerve). Three types of corneal damage are described [12]:

- superficial keratitis, usually early, with punctate or pseudodendritic appearance,

- later stromal keratitis,

- neuro paralytic keratitis.

More or less early complications of varying severity can be observed after herper zoster ophthalmic us. These include persistent pain, eye complications such as decreased visual acuity or even irreversible blindness because of corneal perforation, retinal damage or optic neuritis [2].

\section{Conclusion}

Despite the mildness of varicella and the relative rarity of zoster in children, the severity of zoster complications should make consider children immunization. The ideal would be the use of an acellular vaccine that would be effective without risk of post-vaccinal disease and safe for immunocompromised children. It could also be given to pregnant women who have not had varicella, in order to prevent herpes zoster in children. 


\section{References}

[1] McCrary, M.L., Severson, J. and Tyring, S.K. (1999) Varicella Zoster Virus. Journal of the American Academy of Dermatology, 41, 1-14; quiz 15-16. http://dx.doi.org/10.1016/s0190-9622(99)70398-1

[2] Schaftenaar, E., Meenken, C., Baarsma, G.S., McIntyre, J.A., Verjans, G.M. and Peters, R.P. (2016) Early- and Late-Stage Ocular Complications of Herpes Zoster Ophthalmicus in Rural South Africa. Tropical Medicine \& International Health, 21, 334-339. http://dx.doi.org/10.1111/tmi.12654

[3] Ahn, K.H., Park, Y.J., Hong, S.C., Lee, E.H., Lee, J.S., Oh, M.J. and Kim, H.J. (2016) Congenital Varicella Syndrome: A Systematic Review. Journal of Obstetrics and Gynaecology, 10, $1-4$.

[4] Smith, C.K. and Arvin, A.M. (2009) Varicella in the Fetus and Newborn. Seminars in Fetal and Neonatal Medicine, 14, 209-217. http://dx.doi.org/10.1016/j.siny.2008.11.008

[5] Ortiz-Brugués, A., et al. (2013) Herpes Zoster. Diseminado Infantil. Actas Dermo-Sifiliográficas, 104, 441-442. http://dx.doi.org/10.1016/j.ad.2012.05.010

[6] Teran, C.G. and Medows, M. (2013) Herpes Zoster Ophthalmicus in a Healthy Child. BMJ Case Reports. http://dx.doi.org/10.1136/bcr-2013-009702

[7] Oladokun, R.E., Olomukoro, C.N. and Owa, A.B. (2013) Disseminated Herpes Zoster Ophthalmicus in an Immunocompetent 8-Year Old Boy. Clinics and Practice, 3, e16. http://dx.doi.org/10.4081/cp.2013.e16

[8] Lavaju, P., Badhu, B.P. and Shah, S. (2015) Herpes Zoster Ophthalmicus Presenting as Orbital Abscess along with Superior Orbital Fissure Syndrome: A Case Report. Indian Journal of Ophthalmology, 63, 733-735. http://dx.doi.org/10.4103/0301-4738.171006

[9] Bennet, R., Forsgren, M. and Herin, P. (1985) Herpes Zoster in a 2-Week-Old Premature Infant with Possible Congenital Varicella Encephalitis. Acta Paediatrica Scandinavica, 74, 979-981. http://dx.doi.org/10.1111/j.1651-2227.1985.tb10072.x

[10] Betta, M., Laurino, M., Pugliese, A., Guzzetta, G., Landi, A. and Manfredi, P. (2016) Perspectives on Optimal Control of Varicella and Herpes Zoster by Mass Routine Varicella Vaccination. Proceedings of the Royal Society B: Biological Sciences, 283, pii: 20160054.

[11] Gabutti, G., Franchi, M., Maniscalco, L. and Stefanati, A. (2016) Varicella-Zoster Virus: Pathogenesis, Incidence Patterns and Vaccination Programs. Minerva Pediatrica, 68, 213225.

[12] Colin, J. (2015) CEil et virus. In: Offret, H., Ed., Rapport de la Société Française d Ophtalmologie. Paris/Masson, 200; 8: 244-256. 
Submit or recommend next manuscript to SCIRP and we will provide best service for you:

Accepting pre-submission inquiries through Email, Facebook, LinkedIn, Twitter, etc. A wide selection of journals (inclusive of 9 subjects, more than 200 journals)

Providing 24-hour high-quality service

User-friendly online submission system

Fair and swift peer-review system

Efficient typesetting and proofreading procedure

Display of the result of downloads and visits, as well as the number of cited articles

Maximum dissemination of your research work

Submit your manuscript at: http://papersubmission.scirp.org/

Or contact ojped@scirp.org 